\title{
Diversity in trophic interactions of green sea turtles Chelonia mydas on a relatively pristine coastal foraging ground
}

\author{
Derek A. Burkholder ${ }^{1, *}$, Michael R. Heithaus ${ }^{1}$, Jordan A. Thomson ${ }^{2}$, \\ James W. Fourqurean ${ }^{1}$
} ${ }^{1}$ Department of Biological Sciences, Marine Sciences Program, Florida International University, Biscayne Bay Campus,
North Miami, Florida 33181, USA

${ }^{2}$ Evolutionary and Behavioural Ecology Research Group, Department of Biological Sciences, Simon Fraser University, Burnaby, British Columbia, V5A 1S6, Canada

\begin{abstract}
Adult green sea turtles Chelonia mydas are often the largest-bodied herbivores in their communities and may play an important role in structuring seagrass and macroalgal communities. Recent studies, however, suggest that green turtles might be more omnivorous than previously thought. We used animal-borne video and nitrogen and carbon stable isotopic analysis of skin to elucidate diets of green turtles in the relatively pristine seagrass ecosystem of Shark Bay, Australia. Stable isotope values suggested that despite the presence of abundant seagrass resources, turtles assimilated most of their energy from a combination of macroalgae and gelatinous macroplankton (cnidarians and ctenophores). Video data suggested that macroplankton might be the most commonly consumed food source. Also surprising was the considerable variation in $\delta^{13} \mathrm{C}$ values, suggesting long-term dietary specialization by individual turtles. Overall, green turtle foraging under natural conditions may be less stereotyped than previously thought, and diets of green turtles inhabiting apparently similar ecosystems (e.g. seagrass-dominated ecosystems) may vary considerably across geographical regions. The apparently high degree of individual specialization in diets suggests that conservation efforts should account not only for the potential importance of non-benthic food sources for green turtle populations, but also for the possibility that subsets of the population may play different ecological roles and may be differentially vulnerable to anthropogenic impacts.
\end{abstract}

KEY WORDS: Herbivory $\cdot$ Diet $\cdot$ Foraging behavior $\cdot$ Cnidarians $\cdot$ Stable isotopes $\cdot$ Seagrass ecosystem $\cdot$ Animal-borne video $\cdot$ Shark Bay

\section{INTRODUCTION}

Large herbivores, including green sea turtles Chelonia mydas and sirenians, can structure seagrass communities by changing species composition and biomass or short-circuiting detrital cycles (e.g. Thayer \& Engel 1982, Bjorndal 1997, Aragones \& Marsh 2000, Moran \& Bjorndal 2005, Aragones et al. 2006). For example, green turtles considerably shorten the decomposition time of some seagrass species (e.g. Thalassia testudinum; Thayer \& Engel 1982), and nitrogen-rich fecal matter may stimulate the production of seagrasses, many of which are nitrogen-limited (Thayer \& Engel 1982, Carruthers et al. 2002). Turtle grazing also may increase seagrass forage quality by promoting the growth of new leaves, which have higher nutrient content and lower lignin content and are digested more easily than old leaves (Bjorndal 1980). Intense herbivory by green turtles may cause shifts in seagrass community struc- 
ture (Kuiper-Linley et al. 2007, Wabnitz et al. 2010) or even result in declines in the biomass present in seagrass communities (Murdoch et al. 2007, Fourqurean et al. 2010). Excluding green turtles from a T. testudinim-dominated seagrass meadow in Bermuda for 1 yr resulted in an increase in seagrass biomass and structural complexity of the seagrass canopy when compared to grazed sites (Fourqurean et al. 2010). Understanding the reliance on seagrasses and other resources for food and how the use of these resources might vary within and among populations is of key importance in estimating the ecological impact of green turtles.

Green turtles are traditionally thought to undergo abrupt ontogenetic shifts in their diets, from carnivory during the pelagic phase of their lives to nearly complete herbivory once they settle in coastal habitats at a curved carapace length (CCL) of 40-44 cm (Chaloupka \& Limpus 2001, Arthur et al. 2008). Neritic green turtle diets have been investigated primarily by comparing available food sources to forage found in mouth contents, lavage samples, stomach contents of dead animals, or fecal matter (e.g. Mortimer 1981, Brand et al. 1999, Seminoff et al. 2002, Arthur et al. 2009). These studies suggest that the diets of neritic-stage green turtles are made up almost exclusively of seagrasses and algae, with actual diet composition driven by the relative availability and quality of these food types (e.g. Bjorndal 1980, Forbes 1994, Brand-Gardner et al. 1999, Read \& Limpus 2002). For example, stomach content analysis of 243 green turtles in Nicaragua showed that a seagrass-dominated diet with Thalassia testudinum accounted for almost $90 \%$ of diets in the northern part of the study while algae were much more prevalent (up to $63 \%$ of diets) in the southern region (Mortimer 1981). In algal-dominated communities of the Gulf of California, Mexico, green turtle diets are comprised of a diverse assemblage of marine algae, with red algae accounting for around $90 \%$ of the diet (Seminoff et al. 2002). Likewise, the diets of neritic green turtles in Moreton Bay, southeastern Queensland, were dominated by a mixture of seagrass and algae. Analysis of digesta boluses throughout the digestive tract, which represent different feeding bouts, suggest that turtles change diets between seagrass and algae, sometimes abruptly (Brand et al. 1999). Traditional diet analysis techniques are advantageous because food items can be identified and quantified; however, they are not without limitations. For example, animals often have empty stomachs, and gut content analysis only provides a snapshot of what has been eaten recently.
Also, the snapshot may be biased by variation in digestibility among prey items with harder items remaining in guts for longer periods than soft-bodied organisms that may become unidentifiable in a very short time (Hyslop 1980).

Stable isotopic analysis has become a widespread tool in ecology that can be used to infer trophic interactions and supplement insights obtained from traditional diet analysis (e.g. Hooker et al. 2001, Post 2002, Felicetti et al. 2003). It is possible to use carbon isotopic values to determine the relative contribution of different primary producers to a consumer's diet because primary producers (e.g. plankton, seagrass, and algae) incorporate ${ }^{12} \mathrm{C}$ and ${ }^{13} \mathrm{C}$ into their tissues at different rates, and carbon isotopes exhibit relatively low rates of fractionation with each trophic transfer (Peterson \& Fry 1987, Hobson \& Clark 1992). Relative trophic level can be determined using the ratio of ${ }^{15} \mathrm{~N}:{ }^{14} \mathrm{~N}$ because of trophic enrichment of ${ }^{15} \mathrm{~N}$ in a consumer's tissues relative to that of its prey (DeNiro \& Epstein 1981, Minagawa \& Wada 1984). Stable isotopic values, however, may be hard to interpret in the absence of other techniques (e.g. stomach contents, direct observations) for assessing trophic interactions because isotopic values represent average diets and different diet combinations may lead to similar isotopic values in a consumer.

Both stable isotopes and diet analysis as well as behavioral studies have revealed that there can be considerable and consistent variation in behaviors and diets among individuals of a population, including those of the same age/sex class (e.g. Estes et al. 2003, Bearhop et al. 2004, Svanback \& Bolnick 2005, 2007, Vander Zanden et al. 2010, Matich et al. 2011; see Bolnick et al. 2003 for a review). Understanding patterns and factors driving this 'individual specialization,' in which groups of individuals specialize on a subset of resources used by the population as a whole, is important because it can play an important role in population, community, and evolutionary dynamics and may impact conservation planning (e.g. Baird et al. 1992, Bolnick et al. 2003, Araújo et al. 2009, Newsome et al. 2009, Hammerschlag-Peyer \& Layman 2010). In general, individual specialization should be more likely if (1) resources are scarce, (2) individuals can only forage efficiently on a subset of resources, (3) cognitive constraints limit the use of diverse sets of resources, (4) foraging specializations are transmitted culturally, (5) different habitats have different resource pools and individuals only inhabit a subset of habitats, or (6) ecological trade-offs result in variation among individuals in resource pools that are accessed (e.g. Rendell \& Whitehead 2001, Estes 
et al. 2003, Svanback \&Persson 2004, Araújo \& Gonzaga 2007, Darimont et al. 2009, Matich et al. 2011, Rosenblatt \& Heithaus 2011).

An increased awareness of patterns of individual specialization has, in part, been facilitated by stable isotopic techniques that can provide a long-term record of foraging. Indeed, patterns of specialization within populations can be estimated by comparing variation in isotopic values within and among individuals using either tissues that leave a serial record of foraging (e.g. turtle scutes, Vander Zanden et al. 2010; hooves, Harrison et al. 2007; whiskers, Newsome et al. 2009) or multiple tissues with different turnover rates that provide evidence of short- and long-term variation in diets within individuals and populations (e.g. Matich et al. 2011). In the absence of these data, assessing the degree of among-individual variation in isotopic values in tissues with long turnover times can provide insights into patterns of specialization because individuals with similar diets should converge on a similar isotopic value. Recent studies using isotopic approaches have raised the possibility of individual specialization in large-bodied marine taxa (e.g. sea otters, Newsome et al. 2009; bull sharks, Matich et al. 2011; American alligators, Rosenblatt \& Heithaus 2011) including loggerhead turtles Caretta caretta (Vander Zanden et al. 2010). However, how widespread individual specialization might be in large-bodied marine taxa, especially potential herbivores like green turtles, remains unclear.

Recent studies have raised the possibility that green turtle foraging may be more complex than previously thought, and in locations outside of the Caribbean basin, turtles may exhibit greater degrees of omnivory. For example, animal-borne imaging suggests that green turtles in Western Australia (Heithaus et al. 2002a) and Queensland (Arthur et al. 2007) may consume significant numbers of gelatinous macroplankton (jellyfish or ctenophores). Similarly, green turtles in the Gulf of California, Mexico, have been recorded consuming 5 invertebrate species, in addition to marine algae (there is no seagrass in these habitats) (Seminoff et al. 2006a). Also, stable isotopic values of scutes from green turtles off the NW African coast suggest that the transition from omnivory to herbivory may be less abrupt than previously documented (Reich et al. 2007), with turtles in some regions continuing to consume animal matter-especially discarded fish from local fisherman - well after settling into coastal habitats (Cardona et al. 2009). These studies highlight the need to employ multiple techniques to accurately assess the diet of marine turtles, including those that can overcome the issues of differential digestibility which are likely for turtles that may consume seagrass and softbodied prey like ctenophores and cnidarians. They also suggest that green turtles may play more varied ecological roles than generally appreciated and that populations may forage on diverse resource pools, which could result in individual specialization (e.g. Vander Zanden et al. 2010).

Most studies of green turtle foraging have occurred in areas where turtle populations have undergone drastic declines (Caribbean and Mexico) (Jackson 1997, Jackson et al. 2001). Therefore, studies of the ecological role of turtle diets in relatively pristine areas are a priority for predicting the dynamics of turtle populations and their ecosystems as turtle populations begin to rebound (Hamann et al. 2010). The objective of the present study was to investigate the foraging ecology of green turtles in a relatively pristine seagrass ecosystem. Specifically, we (1) assessed the relative importance of seagrass, macroalgae, and gelatinous macroplankton in the diets of green turtles using stable isotopic analysis, gastric lavage, and animal-borne imaging; (2) investigated variation in diets among turtle sizes and capture location (nearshore vs. offshore seagrass beds) using stable isotopic analysis; and (3) used stable isotopic signatures to gain insights into the potential for individual specialization in foraging.

\section{MATERIALS AND METHODS}

\section{Study site}

The study was conducted in the eastern gulf of Shark Bay, Western Australia $\left(\sim 25^{\circ} 45^{\prime} \mathrm{S}, 113^{\circ} 44^{\prime} \mathrm{E}\right.$; Fig. 1). Located about $800 \mathrm{~km}$ north of Perth, Shark Bay is a shallow $(<15 \mathrm{~m})$ subtropical bay dominated by extensive seagrass beds, which cover approx. $4000 \mathrm{~km}^{2}$ (Walker et al. 1988). Our study site in the Eastern Gulf is characterized by a series of shallow $(<4.5 \mathrm{~m})$ seagrass banks, separated by deeper channels $(6-11 \mathrm{~m})$ mostly covered by sand.

Listed as a World Heritage Area in 1991, Shark Bay is perhaps one of the most pristine remaining seagrass ecosystems in the world and affords a unique opportunity to examine the effects of large herbivores on seagrass ecosystems (Heithaus et al. 2007). Turtle populations in Shark Bay are large and exhibit characteristics of populations near carrying capacity (Heithaus et al. 2005). The seagrass community is a diverse assemblage of temperate and tropical sea- 


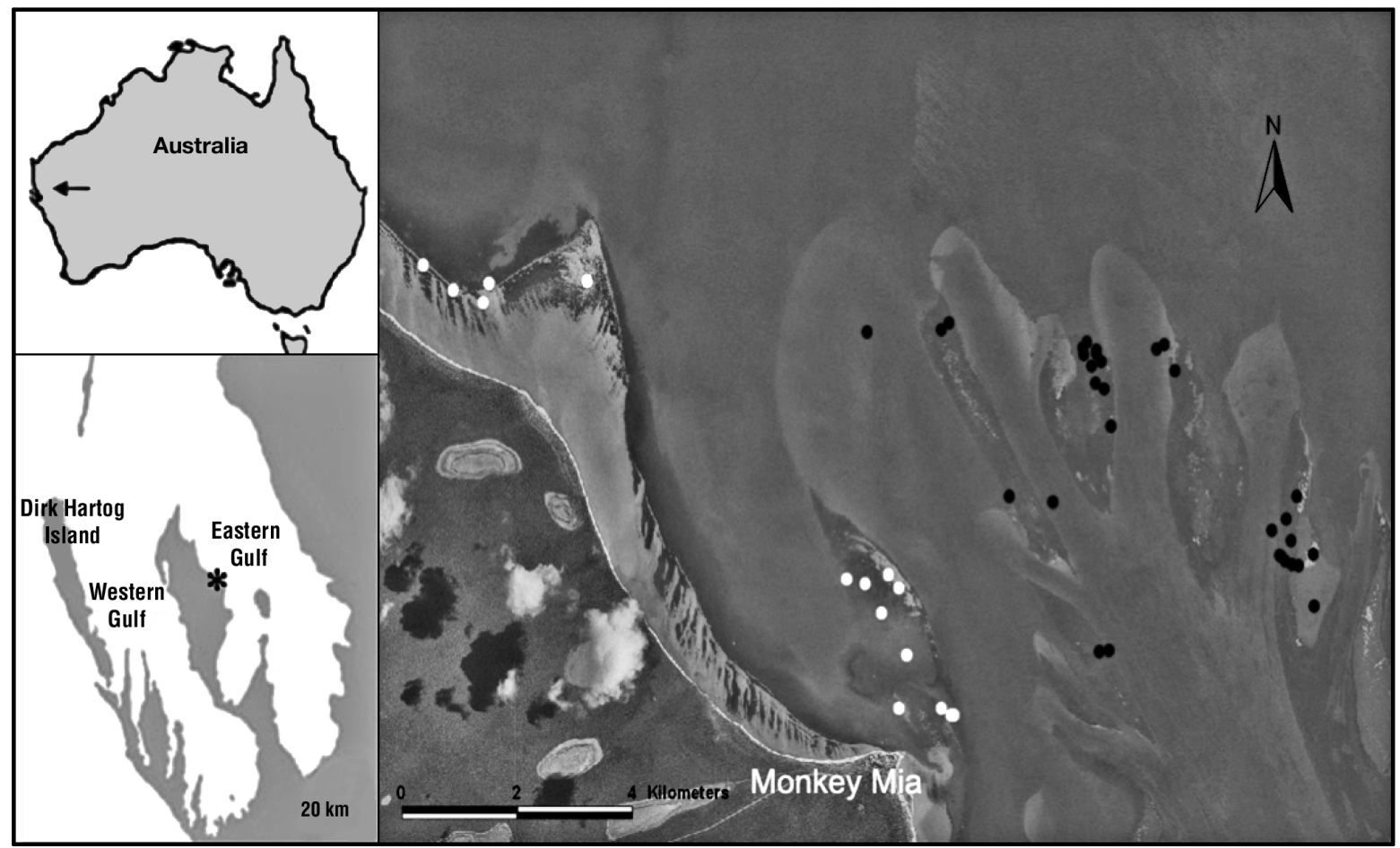

Fig. 1. Location of the study site (*) in the Eastern Gulf of Shark Bay, Western Australia. Points represent capture location of green turtles sampled for stable isotopic composition. White points: captures in the nearshore habitat; black points: captures in the offshore seagrass bank habitat

grass species. The dominant species in the bay are temperate species, including Amphibolis antartica, Posidonia australis, and P. coriacea. Smaller, fastergrowing tropical seagrass species, including Halophila ovalis, H. spinulosa, Halodule uninervis, Cymodocea angustata, Syringodium isoetifolium, Halophila decipiens and H. minor (Walker et al. 1988), are found in lower abundances. Other potential food sources for turtles include several macroalgae species found throughout the study area (D. Burkholder pers. obs.) as well as ctenophores and jellyfish (Heithaus et al. 2002a). Macroalgae are found in relatively low abundance in both deep and shallow habitats (up to 34 and $26 \%$ of the mean aboveground biomass of A. antarctica and P. australia beds, respectively; Walker \& McComb 1988) biomass is very low in beds of tropical species and in areas lacking seagrasses (D. Burkholder pers. obs.). Macroalgae are found primarily growing on large pieces of shell or as epiphytes on A. antarctica in the shallows, or on rare patches of hard bottom exposed in the deeper channels (D. Burkholder pers. obs.). The most common species in shallow habitats are the brown algae Sargassum sp., Padina sp., and Dictyota sp. The red alga Spyridia sp., Laurencia sp., and the green alga Penicillus sp. can be found in the shallows in low densities. Sargassum sp. is the most common species found in deeper waters (D. Burkholder pers. obs.).

\section{Field methods}

From 2006-2009, skin tissue was collected from 65 green turtles to assess stable isotopic values (Fig. 2). Turtles were captured throughout each year using the 'rodeo' technique (Ehrhart \& Ogren 1999, Heithaus et al. 2002b, 2005) in which they were encountered during haphazard searches (targeting for turtle capture for this or other studies) of the study area or during standardized transects run weekly (weather permitting). Sampling took place throughout the year as part of long-term studies of the abundance and habitat use of turtles and other air-breathing taxa, and the majority of samples are from 2006 and 2007. Captured turtles were brought on board the research vessel and tagged with titanium flipper tags (Department of Environment and Conservation, Western Australia). We measured CCL and tail length (tip of tail to carapace). A small skin tissue sample $(3 \times 1$ $\times 1 \mathrm{~cm}$ ) was collected with scissors from the trailing 


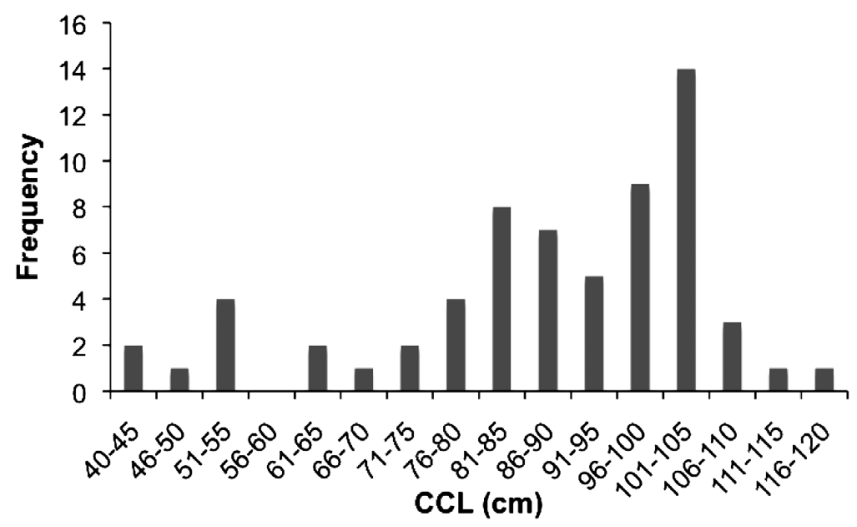

Fig. 2. Chelonia mydas. Size distribution of individuals sampled for stable isotopic analysis. CCL: curved carapace length

edge of the foreflipper. This sample location was chosen to minimize turtle stress. Tissue samples were immediately placed in ice and then stored at $-20^{\circ} \mathrm{C}$ until processing. Turtle captures were categorized into 2 locations: (1) nearshore shallow $(<3 \mathrm{~m})$ habitat dominated by a sand and seagrass bank extending up to $\sim 2 \mathrm{~km}$ from shore (nearshore); and (2) a series of narrow $(3 \mathrm{~km}$ long $\times 0.5 \mathrm{~km}$ wide), shallow offshore seagrass banks separated by deeper $(\sim 10 \mathrm{~m})$ mostly sand bottom channels (offshore) (Fig. 1).

During June and July 2006 we conducted gastric lavage (Forbes \& Limpus 1993) on 3 green turtles. Briefly, turtles were brought onboard the research vessel, inverted, and water was gently pumped into the stomach to flush stomach contents into a sieve. Contents were collected, stored immediately on ice in the field and then stored at $-20^{\circ} \mathrm{C}$ until processing. For analysis, stomach contents were thawed and sorted to the lowest possible taxon under a dissecting microscope. Wet weights were then calculated for each discernible food group. In addition, the stomach contents of one dead green turtle were examined.

Samples of primary producers and primary consumers were collected during stratified benthic sampling of the study site or by haphazard collections when new species were encountered to establish the stable carbon and nitrogen isotopic composition of potential food for green turtles. Primary producers were collected during 2006-2009 from randomly generated point-sampling sites in 3 habitat/microhabitats (deep, middle of shallow seagrass beds, edge of seagrass beds) as part of a larger study of seagrass community composition and nutrient dynamics. Samples were collected either snorkeling or on SCUBA, and sites were sampled both in the summer and winter to elucidate seasonal variation in isotopic values. Gelatinous macroplankton (cnidari- ans and ctenophores) were collected using a $200 \mu \mathrm{m}$ neuston net towed slowly behind our vessel or were collected by hand for larger individuals. Collections were stored on ice and then frozen at $-20^{\circ} \mathrm{C}$ until processing. We collected samples from isopods and a dugong (Dugong dugon) to compare green turtle isotopic values to those of species known to consume primarily seagrasses (i.e. to determine isotopic values that would be expected for green turtles foraging primarily on seagrasses). Isopods were collected using a fine-mesh dip net pushed through seagrass beds. The net contents were sorted and stored on ice for processing. We obtained a lone sample of dugong skin from a recently deceased individual that was stored on ice in the field and frozen at $-20^{\circ} \mathrm{C}$ until processing.

Animal-borne video and environmental data collection systems (AVED; National Geographic's 'Crittercam') were deployed on 17 green turtles from 1999-2003 to monitor foraging behavior of green turtles. The AVED unit, which consisted of a Hi-8 video camera and time-depth recorder inside an aluminum housing (10.1 cm diameter, $31.7 \mathrm{~cm}$ in length) that was fitted with a VHF transmitter, was attached to the turtle by securing a plexiglass baseplate using cool-setting epoxy (Ten-Set ${ }^{\mathrm{TM}}$ ) to the carapace and then attaching the camera to this plate using a wire and magnesium washer. The camera was positioned so that the head was in view and programmed to release from the turtle after 3-24 $\mathrm{h}$ by a burnwire mechanism or a dissolving magnesium washer (see Heithaus et al. 2002a for further details).

\section{Laboratory methods and analysis}

Turtle and dugong tissue collected for isotopic analysis was rinsed in deionized (DI) water, cleaned of epiphytes, dried in a food dehydrator (Ezidri Ultra FD1000) for at least $24 \mathrm{~h}$ and then ground to a fine powder. Because of the small amount of tissue in a single dehydrated ctenophore or jellyfish, 10-20 individuals (depending on size) collected from the same tow or sample area were combined to form a single sample of gelatinous macroplankton for analysis. For these taxa, samples were dehydrated immediately after returning from the field and then powdered. Isopods were dried as whole individuals and ground to a fine powder. For all plant material, a razor blade was used to scrape epiphyte/epibiota from leaves and stems prior to dehydration and isotopic values of epibiota were analyzed separately. Leaf material was separated from stem material (in 
Amphibolis sp.) or from root and rhizome material (for all other seagrass species), and tissues were analyzed separately. At least 5 plants were collected for each species of seagrass at each sampling point, and a subsample of each of those 5 plants was combined to form a single sample for that time/site. For seagrass, algae, and isopods we analyzed carbon isotopic signatures both with and without acidification procedures. If acidification resulted in changes in carbon isotopic values of more than $0.3 \%$, then, acidified $\delta^{13} \mathrm{C}$ values were used. Acidification involved spreading a thin layer of powder in a glass petri dish and placing it in a sealed chamber that contained an open container of hydrochloric acid for at least $24 \mathrm{~h}$. The tissue was then dehydrated and powdered. Lipid extraction was not performed on any samples because the $\mathrm{C}: \mathrm{N}$ ratios indicated that lipid corrections were not necessary (i.e. $\mathrm{C}: \mathrm{N}<3.5$, as in Post et al. 2007; $\mathrm{C}: \mathrm{N}$ flipper tissue $=3.0 \pm 0.2 \mathrm{SD}$ ). Likewise most of the $\mathrm{C}: \mathrm{N}$ ratios of the prey individuals indicated that lipid extraction or correction was not necessary, and for the small number of samples with C:N $>3.5$, we corrected $\delta^{15} \mathrm{~N}$ values according to equations in Post et al. (2007).

For analysis, 0.95-1.05 mg for animal samples, 3.95-4.05 mg for plant and algae samples, and 9-11 mg for ctenophore/cnidarian samples were weighed into tin capsules and analyzed for carbon and nitrogen isotope ratios at either University of Western Australia's Western Australia Biogeochemistry Center or Yale University's Earth System Center for Stable Isotopic Studies.

\section{Analysis of stable isotopic values}

We tested the effects of turtle size and location (nearshore vs. offshore seagrass banks) on $\delta^{13} \mathrm{C}$ and $\delta^{15} \mathrm{~N}$ signatures using general linear models. To investigate the size of the isotopic trophic niche of green turtles in Shark Bay relative to other consumers in Shark Bay, we calculated Layman et al.'s (2007) total area (TA) metric using the Animal Movement extension in ArcView 3.2. The total area metric provides a way to quantify the isotopic trophic diversity within a species and is calculated as the area of the minimum convex polygon that encompasses all individuals. We performed rarefaction analysis to determine if our sample size adequately captured the total isotopic area occupied by green turtles. We considered the sample size to be adequate if a regression through the final 4 points of the rarefaction curve failed to display a slope significantly different from 0
(Bizzarro et al. 2007). Because previous studies have suggested ontogenic changes in the diets/tissue isotope values of green turtles when they reach a CCL of $60 \mathrm{~cm}$, we conducted analyses of TA separately for all turtles and for turtles $\geq 60 \mathrm{~cm}$ CCL (Cardona et al. 2009, 2010).

We used MixSir, a Bayesian-mixing model that accounts for variation in isotopic discrimination and source values (Moore \& Semmens 2008), to estimate the relative contributions of algae, seagrasses, and gelatinous macroplankton to the diets of green turtles in Shark Bay. These potential food sources were chosen based on studies of green turtle diets in other parts of Australia as well as video data collected from green turtles in the study area. We assumed only a single trophic transfer (direct consumption of prey items by turtles) between these resource pools and turtles. We conducted analyses separately for turtles $<60 \mathrm{~cm}$ CCL and $\geq 60 \mathrm{~cm}$ CCL. In addition, because of seasonal differences in the isotopic signatures of potential food sources, we conducted separate analyses for winter (June to August) and summer (September to May) for turtles $\geq 60 \mathrm{~cm}$ CCL (sample sizes were not adequate for seasonal analysis of turtles $<60 \mathrm{~cm})$. Because discrimination factors are not known for neritic green turtles, we conducted MixSir modeling using 3 different estimates of discrimination factors that together should provide robust insights into trophic interactions of turtles. First, we used ${ }^{13} \mathrm{C}$ and ${ }^{15} \mathrm{~N}$ discrimination factors measured in juvenile green turtles Chelonia mydas fed on a carnivorous diet (Seminoff et al. 2006b; skin tissue: ${ }^{15} \mathrm{~N}=$ $2.80 \pm 0.11 \%{ }^{13}{ }^{13} \mathrm{C}=0.17 \pm 0.03 \%$ ). Second, because green turtles are thought to be primarily herbivorous and use hind-gut fermentation, which can result in substantially different discrimination factors, we used ${ }^{13} \mathrm{C}$ and ${ }^{15} \mathrm{~N}$ discrimination factors, measured in Florida manatees Trichechus manatus latirostris, a large-bodied marine hind-gut fermenting herbivore (Alves-Stanley \& Worthy 2009; skin tissue: ${ }^{15} \mathrm{~N}$ [estimated $]=5.0 \pm 0.00 \%,{ }^{13} \mathrm{C}=2.80 \pm 0.09 \%$ o). Finally, we used average ${ }^{13} \mathrm{C}$ and ${ }^{15} \mathrm{~N}$ discrimination factors based on meta-analysis of isotopic studies by Caut et al. (2009) $\left({ }^{15} \mathrm{~N}=2.75 \pm 0.1 \%\right.$; $\delta^{13} \mathrm{C}=0.75 \pm 0.11 \%$ ). We used 25000000 iterations for each season, and size grouping. We conducted 5000000 iterations to explore the mix of food resources used by individual turtles exhibiting peripheral stable isotopic values of the population's TA.

Because green turtles consume seagrass and its epiphytes simultaneously, we conducted a second set of all MixSir models described above using a combined 'seagrass + epiphytes' resource pool. Since we 
do not have data on the relative biomass of epiphytes and seagrass in our samples, we combined means and standard deviations using the maximum proportion of epiphytes to seagrass tissue for Amphibolis griffighi (50\% of total aboveground biomass, Borowitzka et al. 1990; estimates for species in our study area were not available). This should provide an upper estimate of the contribution of the seagrass/ epiphyte resource pool to green turtle diets (under the assumptions of the mixing model) since epiphytes have $\delta^{13} \mathrm{C}$ values that are slightly more negative than those of seagrass (see 'Results').

\section{Video analysis}

Video footage was analyzed for foraging behavior and foraging rates of green turtles. In many cases, food items, especially seagrasses and macroalgae, could be identified as the turtle approached and fed. Foraging on gelatinous macroplankton was primarily observed while traveling midwater, and although it was possible to see prey being captured in many cases, sometimes foraging was inferred from turtle head movements identical to those when prey capture was observed followed by neck movements consistent with swallowing (Heithaus et al. 2002a). We quantified the number of ctenophores and jellyfish consumed as well as the number of bites of macroalgae and seagrass consumed by each turtle.

\section{RESULTS}

\section{Stable isotope values of basal resource pools and herbivores}

Potential food sources for green turtles displayed relatively unique isotopic signatures. Tropical seagrass species (Halophila ovalis, H. spinulosa, Halodule uninervis, Cymodocea angustata, Syringodium isoetifolium) had $\delta^{13} \mathrm{C}$ values between -4.6 and $-12.2 \%$ while temperate seagrass species Amphibolis antarctica and Posidonia australis showed lower $\delta^{13} \mathrm{C}(-8.0$ to $-13.3 \%$ ), and seagrass epibiota varied from -8.2 to $-15.2 \%$ o (Fig. 3). Macroalgae had lower $\delta^{13} \mathrm{C}$ values than seagrass and ranged between -12.0 and $-24.1 \%$. The range of $\delta^{13} \mathrm{C}$ of gelatinous macroplankton (-15.1 to $-19.8 \%$ ) was similar to that of macroalgae, suggesting that planktonic microalgae are similar in $\delta^{13} \mathrm{C}$ to macroalgae. The $\delta^{13} \mathrm{C}$ of Sargassum sp. ranged from -12.04 to -16.89 (mean $=$ $-14.15 \pm 1.46 \%$ SE), Padina sp. ranged from -14.20 to -17.88 (mean $=-16.66 \pm 1.16 \%$ o SE), Dictyota sp. ranged from -13.28 to -16.40 (mean $=-15.16 \pm$ $1.10 \%$ SE), Laurencia sp. ranged from -20.11 to -24.05 (mean $=-22.31 \pm 2.06 \%$ SE), and Penicillus sp. ranged from -13.74 to -15.24 (mean $=-14.31 \pm$ $0.80 \%$ SE). There was significant seasonal variation in $\delta^{13} \mathrm{C}$ of gelatinous macroplankton ( $\mathrm{n}=10$ in summer, $\mathrm{n}=7$ in winter, $F_{1,15}=45.2, \mathrm{p}<0.001$ ) with lower $\delta^{13} \mathrm{C}$ in winter (mean $=-19.7 \pm 0.2 \% \mathrm{SE}$ ) than sum-

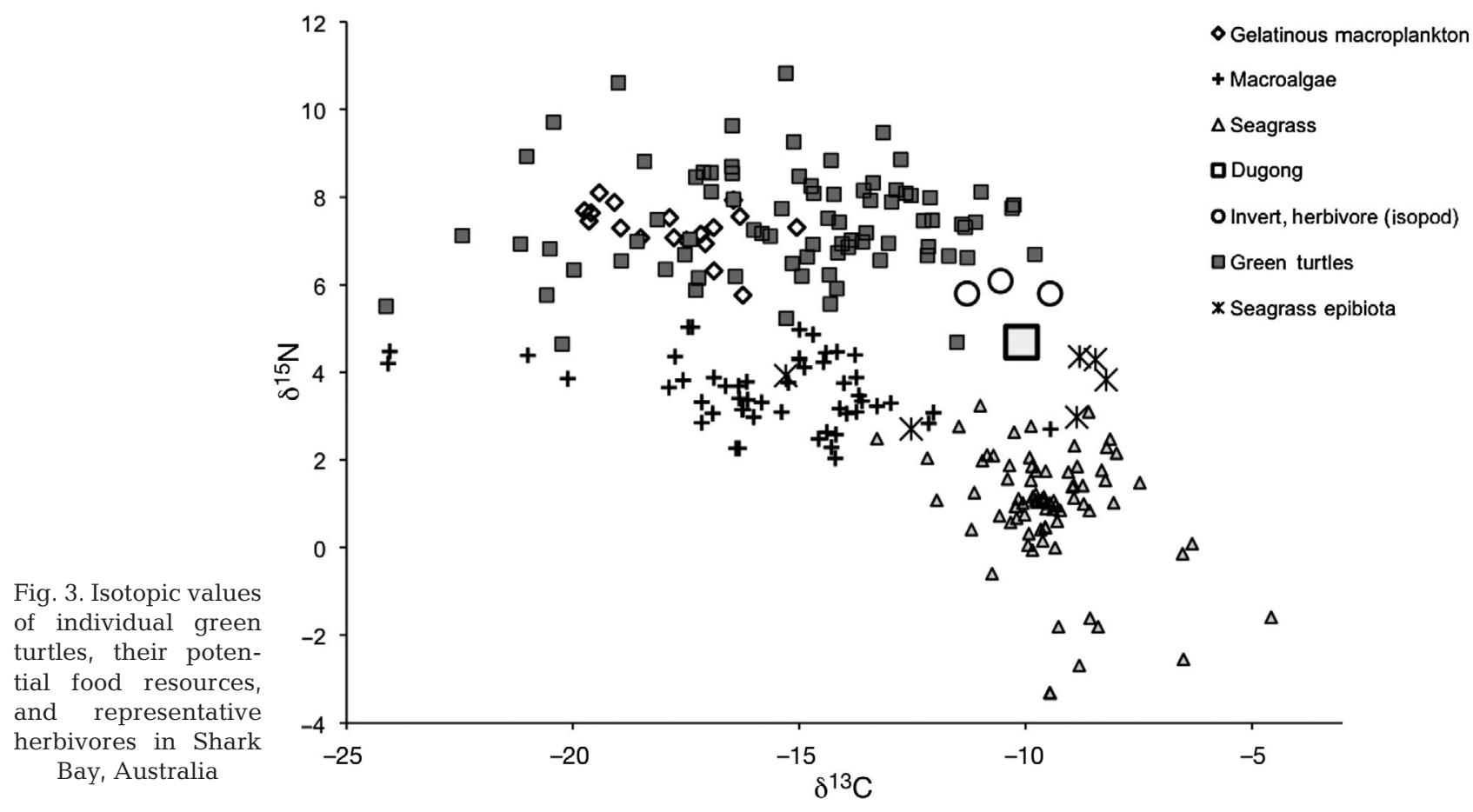


mer (mean $=-17.9 \pm 0.2 \% \mathrm{SE}$ ). The $\delta^{15} \mathrm{~N}$ values of gelatinous macroplankton also varied seasonally $\left(F_{1,15}=8.1, \mathrm{p}=0.01\right)$ with higher $\delta^{15} \mathrm{~N}$ in winter (mean $=7.6 \pm 0.2 \% \mathrm{SE}$ ) than summer (mean $=6.8 \pm 0.2 \%$ $\mathrm{SE}$ ). Importantly for our mixing models, the $\delta^{15} \mathrm{~N}$ values of macroalgae (range $=2.0-5.0 \%$ ) were lower than those of gelatinous macroplankton, but were higher than those of seagrasses, which ranged from -3.3 to $+3.2 \%$ o (Fig. 3). The $\delta^{15} \mathrm{~N}$ of Sargassum sp. ranged from 2.48 to 4.86 (mean $=3.53 \pm 0.67 \% \mathrm{SE}$ ), Padina sp. ranged from 2.04 to 5.03 (mean $=3.44 \pm$ $0.89 \%$ SE), Dictyota sp. ranged from 2.27 to 4.98 (mean $=3.55 \pm 0.93 \% \mathrm{SE}$ ), Laurencia sp. ranged from 3.86 to 4.48 (mean $=4.23 \pm 0.27 \% \mathrm{SE}$ ), and Penicillus sp. ranged from 3.75 to 3.88 (mean $=3.80 \pm 0.07 \%$ o $\mathrm{SE})$. There was no significant seasonal variation in seagrass $\left(A\right.$. antarctica) $\delta^{13} \mathrm{C}(\mathrm{n}=33$ in summer, $\mathrm{n}=17$ in winter, $\left.F_{1,48}=0.2, \mathrm{p}=0.66\right)$ or $\delta^{15} \mathrm{~N}\left(F_{1,48}=2.0, \mathrm{p}=\right.$ $0.17)$. Macroalgae showed no seasonal variation in $\delta^{13} \mathrm{C}\left(\mathrm{n}=22\right.$ in summer, $\mathrm{n}=29$ in winter, $F_{1,49}=$ $0.0006, \mathrm{p}=0.98)$, but their $\delta^{15} \mathrm{~N}$ was significantly higher in the summer (mean $=4.0 \pm 0.1 \% \mathrm{SE}$ ) than winter $\left(\right.$ mean $=3.3 \pm 0.1 \%$ o SE) $\left(F_{1,49}=14.3, \mathrm{p}=\right.$ $0.0004)$.

Invertebrate grazers found on seagrasses (isopods) and a dugong, which is known to consume seagrass almost exclusively, had similar isotopic values. The $\delta^{13} \mathrm{C}$ values were near $-10 \%$, which is similar to that of seagrass, while $\delta^{15} \mathrm{~N}$ ranged between 4.7 and $6.1 \%$ for isopods and dugong (Fig. 3).

\section{Green turtle trophic relationships}

\section{Stable isotopes}

The $\delta^{13} \mathrm{C}$ values of green turtles $(\mathrm{n}=65)$ ranged from -22.4 to $-9.8 \%$ (mean $=-15.0 \pm 3.0 \%$ SD) and $\delta^{15} \mathrm{~N}$ ranged from 4.7 to $10.8 \%$ o (mean $=7.7 \pm 1.1 \%$ $\mathrm{SD})$, suggesting that turtles fed at more than one trophic level. There was no effect of CCL on $\delta^{13} \mathrm{C}$ and $\delta^{15} \mathrm{~N}\left(\delta^{13} \mathrm{C}: F_{1,63}=0.0001, \mathrm{p}=0.99 ; \delta^{15} \mathrm{~N}: F_{1,63}=2.7, \mathrm{p}\right.$ $=0.11$; Fig. 4 ) or between offshore banks and nearshore shallows $(\mathrm{n}=23$ for nearshore, $\mathrm{n}=32$ for offshore seagrass banks; $\delta^{13} \mathrm{C}: F_{1,53}=0.8, \mathrm{p}=0.38$; $\delta^{15} \mathrm{~N}: F_{1,53}=2.8, \mathrm{p}=0.10$ ).

The considerable variation in isotopic values of both $\delta^{15} \mathrm{~N}$ and $\delta^{13} \mathrm{C}$ resulted in large areas of isotopic niche space being occupied relative to other species in Shark Bay (see 'Discussion'). The isotopic values of all 65 turtles with flipper tissue samples occupied 52.3 units $^{2}$ of area while the 57 turtles $\geq 60 \mathrm{~cm} \mathrm{CCL}$ occupied 42.4 units $^{2}$ of area. Rarefaction analysis
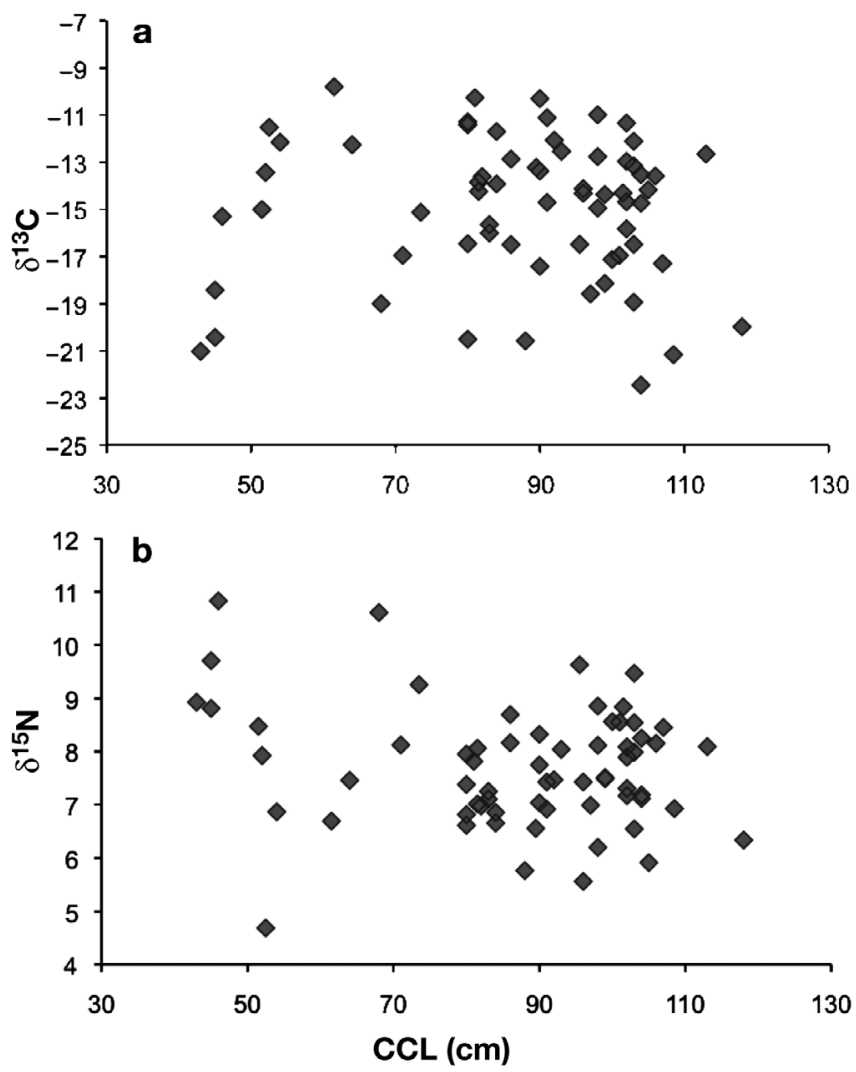

Fig. 4. Chelonia mydas. Influence of curved carapace length (CCL, in cm) on (a) $\delta^{13} \mathrm{C}$ and (b) $\delta^{15} \mathrm{~N}$ values

suggested that our sample of individuals adequately captured the total isotopic area occupied by green turtles for skin tissue $\left(F_{1,3}=2.5, \mathrm{p}=0.25\right)$.

On the basis of 3 estimates of isotopic discrimination (see 'Materials and methods') as well as the assumption that green turtles are limited to gelatinous macroplankton, macroalgae, and seagrasses in Shark Bay, green turtles overall assimilate strikingly little carbon from seagrasses (Table 1). Stable isotopes strongly suggest that green turtles of all size classes in Shark Bay are dependant mostly on macroalgae and gelatinous macroplankton. The median contribution of seagrasses to green turtles was always less than $10 \%$ regardless of discrimination assumptions. Even the 95th percentile estimates suggested a $<16 \%$ contribution by seagrasses to green turtle diets. Adding epiphytes to the seagrass in the mixing model resulted in very little change in the estimated contribution of this complex to assimilated carbon. In comparison, running the MixSIR model for one single skin tissue sample from an obligate herbivore, the dugong in this study, using the discrimination factors for a close relative, the manatee, resulted in median estimates of $75 \%$ sea- 
Table 1. Chelonia mydas. Estimated diet compositions of green turtles in Shark Bay, Western Australia, based on 3 assumptions about isotopic discrimination factors. Two sets of MixSir, a Bayesian-mixing model, were used. Skin tissue taken from the flipper was analyzed in both sets. Seagrass was run as a resource pool without epiphytes in Set 1 but with epiphytes in Set 2. Isotopic values of potential food sources used in models: algae $\left(\delta^{13} \mathrm{C}=-15.55 \pm 2.61 ; \delta^{15} \mathrm{~N}=3.52 \pm 0.75\right)$, seagrass $\left(\delta^{13} \mathrm{C}=-9.41\right.$ $\pm 1.32 ; \delta^{15} \mathrm{~N}=0.77 \pm 1.62$ ), gelatinous macroplankton (gel. macropl.) combined for $<60 \mathrm{~cm}$ curved carapace length (CCL) $\left(\delta^{13} \mathrm{C}=-17.68 \pm 1.40 ; \delta^{15} \mathrm{~N}=7.24 \pm 0.56\right)$, gel. macropl. in summer $\left(\delta^{13} \mathrm{C}=-17.89 \pm 0.68 ; \delta^{15} \mathrm{~N}=6.82 \pm 0.65\right)$, gel. macropl. in winter $\left(\delta^{13} \mathrm{C}=-19.27 \pm 0.27 ; \delta^{15} \mathrm{~N}=7.58 \pm 0.35\right)$. Values are medians with 5 th and 95th percentiles in parentheses

\begin{tabular}{|c|c|c|c|c|c|}
\hline \multirow[b]{2}{*}{ Set 1} & \multirow[b]{2}{*}{$\mathrm{N}$} & \multirow[b]{2}{*}{ Assumption } & \multirow[b]{2}{*}{ Algae } & \multirow{2}{*}{$\begin{array}{l}\text { Resource pool- } \\
\text { Gel. macropl. }\end{array}$} & \multirow[b]{2}{*}{ Seagrass } \\
\hline & & & & & \\
\hline \multirow[t]{3}{*}{ Turtles $<60 \mathrm{~cm}$ CCL } & 8 & Seminoff et al. (2006b) & $0.87(0.74-0.98)$ & $0.12(0.02-0.26)$ & $0.00(0.00-0.02)$ \\
\hline & 8 & Caut et al. (2009) & $0.86(0.72-0.98)$ & $0.14(0.02-0.27)$ & $0.00(0.00-0.02)$ \\
\hline & 8 & Alves-Stanley \& Worthy (2009) & $0.96(0.94-1.00)$ & $0.01(0.00-0.04)$ & $0.01(0.00-0.04)$ \\
\hline \multicolumn{6}{|l|}{ Turtles $\geq 60 \mathrm{~cm} \mathrm{CCL}$} \\
\hline \multirow[t]{3}{*}{ All seasons } & 57 & Seminoff et al. (2006b) & $0.77(0.73-0.80)$ & $0.23(019-0.27)$ & $0.00(0.00-0.01)$ \\
\hline & 57 & Caut et al. (2009) & $0.74(0.70-0.78)$ & $0.26(0.22-0.29)$ & $0.00(0.00-0.01)$ \\
\hline & 57 & Alves-Stanley \& Worthy (2009) & $0.98(0.95-1.00)$ & $0.00(0.00-0.01)$ & $0.02(0.00-0.05)$ \\
\hline \multirow[t]{3}{*}{ Summer } & 26 & Seminoff et al. (2006b) & $0.81(0.75-0.87)$ & $0.19(0.12-0.25)$ & $0.00(0.00-0.02)$ \\
\hline & 26 & Caut et al. (2009) & $0.79(0.73-0.86)$ & $0.20(0.14-0.26)$ & $0.00(0.00-0.01)$ \\
\hline & 26 & Alves-Stanley \& Worthy (2009) & $0.99(0.96-1.00)$ & $0.00(0.00-0.01)$ & $0.01(0.00-0.04)$ \\
\hline \multirow[t]{3}{*}{ Winter } & 31 & Seminoff et al. (2006b) & $0.78(0.74-0.83)$ & $0.21(0.17-0.25)$ & $0.00(0.00-0.02)$ \\
\hline & 31 & Caut et al. (2009) & $0.75(0.71-0.79)$ & $0.25(0.21-0.29)$ & $0.00(0.00-0.02)$ \\
\hline & 31 & Alves-Stanley \& Worthy (2009) & $0.89(0.83-0.96)$ & $0.01(0.00-0.02)$ & $0.10(0.04-0.16)$ \\
\hline Set 2 & $\mathrm{~N}$ & Assumption & Algae & Gel. macropl. & Seagrass + Epiphytes \\
\hline \multirow[t]{3}{*}{ Turtles $<60 \mathrm{~cm} \mathrm{CCL}$} & 8 & Seminoff et al. (2006b) & $0.87(0.74-0.98)$ & $0.12(0.02-0.25)$ & $0.01(0.00-0.02)$ \\
\hline & 8 & Caut et al. (2009 & $0.86(0.73-0.97)$ & $0.13(0.02-0.27)$ & $0.00(0.00-0.02)$ \\
\hline & 8 & Alves-Stanley \& Worthy (2009) & $0.96(0.93-0.99)$ & $0.01(0.00-0.04)$ & $0.01(0.00-0.05)$ \\
\hline \multicolumn{6}{|l|}{ Turtles $\geq 60 \mathrm{~cm}$ CCL } \\
\hline \multirow[t]{3}{*}{ Summer } & 26 & Seminoff et al. (2006b) & $0.81(0.75-0.87)$ & $0.19(0.12-0.25)$ & $0.01(0.00-0.02)$ \\
\hline & 26 & Caut et al. (2009) & $0.79(0.73-0.86)$ & $0.20(0.14-0.26)$ & $0.00(0.00-0.02)$ \\
\hline & 26 & Alves-Stanley \& Worthy (2009) & $0.99(0.97-1.00)$ & $0.00(0.00-0.01)$ & $0.01(0.00-0.03)$ \\
\hline \multirow[t]{3}{*}{ Winter } & 31 & Seminoff et al. (2006b) & $0.78(0.74-0.83)$ & $0.21(0.17-0.25)$ & $0.00(0.00-0.02)$ \\
\hline & 31 & Caut et al. (2009) & $0.75(0.71-0.79)$ & $0.25(0.21-0.29)$ & $0.00(0.00-0.02)$ \\
\hline & 31 & Alves-Stanley \& Worthy (2009) & $0.89(0.79-0.98)$ & $0.00(0.00-0.02)$ & $0.10(0.01-0.20)$ \\
\hline
\end{tabular}

grass, $15 \%$ algae, and $8 \%$ gelatinous macroplankton contribution to the diet. The 8 turtles $<60 \mathrm{~cm}$ appear to have assimilated the large majority of their energy from macroalgae; fractionation assumptions had little effect on the estimated contribution of macroalgae with median contributions above $86 \%$ for all analyses (Table 1). Discrimination factor assumptions had much larger effects on predicted use of macroalgae vs. gelatinous macroplankton of turtles $\geq 60 \mathrm{~cm}$. Based on analysis of skin tissue, median contributions were ca. $15-25 \%$ for gelatinous macroplankton and ca. $75-85 \%$ for macroalgae, based on discrimination assumptions for juvenile green turtles and average discrimination factors across taxa (Table 1). Manatee discrimination factors, however, greatly shifted predicted ratios, with macroalgae estimated to make up the vast majority of the assimilated diets and gelatinous macroplankton contributing virtually nothing to diets (Table 1). MixSir suggested considerable individual variation in the relative mixes of algae, seagrasses, and ctenophores/cnidarians in the diets of individual green turtles (Table 2). Predicted resource use by individuals ranged from almost exclusive reliance on either gelatinous macroplankton or macroalgae to heavy reliance on seagrasses and most of the possible combinations in between (Fig. 3, Table 2). Even the manatee discrimination factors suggested that some individuals consumed considerable amounts of gelatinous macroplankton.

\section{Lavage}

Food items recovered from lavage supported the trends in diets suggested by stable isotopic analysis. Although the sample size was low $(\mathrm{n}=3)$, each individual had a considerable amount of food in its crop, but the compositions of the lavage contents were strikingly different. One sample contained only macerated seagrass (primarily Amphibolis antarctica) tis- 
Table 2. Chelonia mydas. MixSir predicted diet compositions for extreme individual turtles (animals selected at extreme range of the carbon and nitrogen spectrums to encompass all possible values) based on discrimination factors of juvenile green turtles (Seminoff et al. 2006b) and juvenile loggerhead turtles (Reich et al. 2008). Values are medians with 5th and 95th percentiles in parentheses. U: unclassed; M: male; Gel. macropl.: gelatinous macroplankton

\begin{tabular}{|c|c|c|c|c|c|c|}
\hline Length & Sex & $\delta^{15} \mathrm{~N}$ & $\delta^{13} \mathrm{C}$ & Algae & $\begin{array}{l}\text { Resource pool- } \\
\text { Gel. macropl. }\end{array}$ & Seagrass \\
\hline \multicolumn{7}{|c|}{ Seminoff et al. (2006b) } \\
\hline 61.5 & U & 6.69 & -9.80 & $0.18(0.01-0.86)$ & $0.08(0.01-0.21)$ & $0.72(0.07-0.91)$ \\
\hline 68.0 & $\mathrm{U}$ & 10.61 & -19.00 & $0.03(0.00-0.13)$ & $0.95(0.86-0.99)$ & $0.01(0.00-0.05)$ \\
\hline 104.0 & $\mathrm{U}$ & 7.12 & -22.44 & $0.84(0.66-0.96)$ & $0.12(0.01-0.30)$ & $0.03(0.00-0.10)$ \\
\hline 96.0 & M & 5.56 & -14.31 & $0.44(0.06-0.81)$ & $0.19(0.02-0.48)$ & $0.36(0.11-0.55)$ \\
\hline 88.0 & $\mathrm{U}$ & 5.76 & -20.58 & $0.85(0.69-0.96)$ & $0.07(0.01-0.21)$ & $0.06(0.01-0.19)$ \\
\hline 95.5 & $\mathrm{U}$ & 9.63 & -16.48 & $0.09(0.01-0.36)$ & $0.69(0.59-0.76)$ & $0.22(0.01-0.31)$ \\
\hline 103.0 & $\mathrm{U}$ & 9.47 & -13.15 & $0.06(0.00-0.29)$ & $0.37(0.19-0.48)$ & $0.56(0.40-0.71)$ \\
\hline 80.0 & $\mathrm{U}$ & 6.61 & -11.29 & $0.27(0.02-0.82)$ & $0.17(0.02-0.35)$ & $0.55(0.08-0.79)$ \\
\hline \multicolumn{7}{|c|}{ Caut et al. (2009) } \\
\hline 61.5 & U' & 6.69 & -9.80 & $0.20(0.01-0.83)$ & $0.13(0.02-0.31)$ & $0.63(0.07-0.86)$ \\
\hline 68.0 & $\mathrm{U}$ & 10.61 & -19.00 & $0.03(0.00-0.12)$ & $0.94(0.85-0.98)$ & $0.02(0.00-0.07)$ \\
\hline 104.0 & $\mathrm{U}$ & 7.12 & -22.44 & $0.85(0.67-0.97)$ & $0.11(0.01-0.29)$ & $0.03(0.00-0.10)$ \\
\hline 96.0 & M & 5.56 & -14.31 & $0.53(0.12-0.86)$ & $0.15(0.01-0.43)$ & $0.32(0.07-0.51)$ \\
\hline 88.0 & $\mathrm{U}$ & 5.76 & -20.58 & $0.87(0.72-0.97)$ & $0.06(0.00-0.19)$ & $0.05(0.00-0.17)$ \\
\hline 95.5 & $\mathrm{U}$ & 9.63 & -16.48 & $0.09(0.01-0.26)$ & $0.84(0.70-0.95)$ & $0.05(0.01-0.15)$ \\
\hline 103.0 & $\mathrm{U}$ & 9.47 & -13.15 & $0.08(0.01-0.30)$ & $0.76(0.53-0.91)$ & $0.13(0.01-0.39)$ \\
\hline 80.0 & $\mathrm{U}$ & 6.61 & -11.29 & $0.28(0.02-0.80)$ & $0.22(0.03-0.43)$ & $0.48(0.08-0.73)$ \\
\hline \multicolumn{7}{|c|}{ Alves-Stanley \& Worthy (2009) } \\
\hline 61.5 & $\mathrm{U}$ & 6.69 & -9.80 & $0.26(0.03-0.58)$ & $0.13(0.01-0.24)$ & $0.59(0.36-0.78)$ \\
\hline 68.0 & $\mathrm{U}$ & 10.61 & -19.00 & $0.54(0.08-0.87)$ & $0.44(0.10-0.87)$ & $0.02(0.00-0.08)$ \\
\hline 104.0 & $\mathrm{U}$ & 7.12 & -22.44 & $0.94(0.85-0.99)$ & $0.03(0.00-0.09)$ & $0.03(0.00-0.11)$ \\
\hline 96.0 & M & 5.56 & -14.31 & $0.57(0.41-0.79)$ & $0.03(0.00-0.12)$ & $0.39(0.19-0.53)$ \\
\hline 88.0 & $\mathrm{U}$ & 5.76 & -20.58 & $0.93(0.80-0.99)$ & $0.02(0.00-0.06)$ & $0.04(0.00-0.18)$ \\
\hline 95.5 & $\mathrm{U}$ & 9.63 & -16.48 & $0.63(0.38-0.88)$ & $0.31(0.07-0.54)$ & $0.05(0.00-0.16)$ \\
\hline 103.0 & $\mathrm{U}$ & 9.47 & -13.15 & $0.42(0.07-0.78)$ & $0.41(0.14-0.63)$ & $0.18(0.02-0.36)$ \\
\hline 80.0 & $\mathrm{U}$ & 6.61 & -11.29 & $0.38(0.06-0.68)$ & $0.11(0.01-0.35)$ & $0.49(0.28-0.67)$ \\
\hline
\end{tabular}

sue (wet mass $=1.46 \mathrm{~g})$. A second lavage sample was primarily composed of fleshy red macroalgae Spongiophloea sp. $\left(6.83 \mathrm{~g}_{i} 98 \%\right.$ of total sample wet weight) with small contributions of the filamentous red algae Laurencia sp. $(0.1 \mathrm{~g} ; 1.4 \%$ of total sample wet weight) and macerated seagrass (0.4 $\mathrm{g}$ wet weight; $0.6 \%$ of total mass). The third lavage sample was dominated by the filamentous red algae Laurencea sp. (0.39 g; $93.5 \%$ of total sample wet weight) but also contained macerated seagrass material (0.03 g; $6.5 \%$ of total mass). Skin tissue was run for stable isotopic analysis for the third lavage animal. Running the MixSIR model with the manatee discrimination factors resulted in a median estimated contribution of $67 \%$ macroalgae, $29 \%$ gelatinous macroplankton, and 3\% seagrass, which supports the lavage findings for that individual. Stomach contents of one stranded green turtle, which were not quantified, were dominated by macerated seagrass tissue and gelatinous material (L. Bejder pers. comm.).

\section{Animal-borne video}

Seventeen AVED deployments were made resulting in 12 usable videos for diet analysis (videos with poor camera placement or short $(<90 \mathrm{~min})$ deployment durations were excluded from analysis). Eleven of the 12 turtles for which usable video were obtained (mean duration $=159.4 \mathrm{~min} \pm 7.2$ min SE) recorded foraging during the deployment. Ten of the 12 fed on gelatinous macroplankton, 1 fed on algae, and 2 fed on seagrass. Most of the cnidarians/ctenophores were small, (i.e. $<10 \mathrm{~cm}$ in diameter). However, in one instance, a turtle pulled a large Phyllorhiza sp. jellyfish out of an area of dense Amphibolis antarctica and consumed it over the course of several minutes. Gelatinous macroplankton were consumed at a mean rate of $3.8 \pm 2.2 \mathrm{SE}$ ind. $\mathrm{h}^{-1}$ with a total of 112 items consumed. Macroalgae was consumed at a rate of 3.3 \pm 3.3 SE bites $\mathrm{h}^{-1}$ with a total of 141 bites taken, although all of these were from a single individual. 
Finally, only 7 bites of seagrass were recorded, resulting in a mean foraging rate of $0.2 \pm 0.1 \mathrm{SE}$ bites $\mathrm{h}^{-1}$.

\section{DISCUSSION}

\section{Trophic interactions of green turtles}

Green turtles are widely thought to be important herbivores in seagrass ecosystems through their impacts on growth patterns of seagrasses as well as detrital cycles (e.g. Thayer \& Engel 1982, Bjorndal 1997, Aragones \& Marsh 2000, Moran \& Bjorndal 2005, Aragones et al. 2006, Lal et al. 2010). Indeed, the loss of megaherbivores, including green turtles and sirenians, have been hypothesized to have resulted in extreme changes in seagrass communities, especially in the Caribbean (Bjorndal \& Jackson 1996, Jackson et al. 2001). In seeming contrast, recent studies have suggested that omnivory might be common in green turtles outside of the Caribbean (e.g. Heithaus et al. 2002a, Seminoff et al. 2006a, Arthur et al. 2007, Cardona et al. 2009). Our study suggests that in a relatively pristine Australian seagrass ecosystem the reliance of the green turtle population on seagrass-derived primary production is smaller than would be expected based on the abundance of seagrass resources. There is, however, a large degree of variation in individual turtle diets over time periods of at least months and, therefore, turtle impacts on seagrass communities likely are complex and more diverse than previously thought.

All 3 methods (AVED, stable isotopes, stomach contents) that we used to study turtle diets suggest that although seagrasses are extremely abundant in Shark Bay, neritic green turtles are not exclusively seagrass herbivores and may in fact consume relatively little of the available seagrass. Indeed, very few of the sampled green turtles had $\delta^{13} \mathrm{C}$ similar to those of seagrasses even though other herbivores in the study area-including one hind-gut fermenter (dugong)-did have $\delta^{13} \mathrm{C}$ similar to seagrasses. Green turtle tissues were more deplete in ${ }^{13} \mathrm{C}$ than were seagrasses and other herbivores, which was consistent with turtles assimilating carbon from gelatinous macroplakton and/or macroalgae. Also, many green turtles generally had $\delta^{15} \mathrm{~N}$ values ca. $6 \%$ higher than seagrasses, suggesting the potential for 2 trophic levels of difference, even for some turtles with $\delta^{13} \mathrm{C}$ signatures similar to seagrasses. ${ }^{15} \mathrm{~N}$ values must be interpreted with caution, however, because of potentially large variation in fractionation values for herbivores such as green turtles (Martinez del Rio $\&$ Wolf 2005). Despite this, the sample we obtained from a sympatric hind-gut fermenting herbivore (dugong) had a ${ }^{15} \mathrm{~N}$ much lower than most green turtles, suggesting that the large spread of $\delta^{15} \mathrm{~N}$ in green turtle samples are unlikely to be the result of digestive processes alone. Previous studies using AVED cameras and the additional video data presented here suggest that gelatinous macroplankton (primarily cnidarians and ctenophores) are commonly consumed by green turtles in Australia (Heithaus et al. 2002a, Arthur et al. 2007). It has been hypothesized that the consumption of this animal matter might be a response to capture stress and handling associated with the attachment of AVED (Arthur et al. 2007). Data from stable isotopes in Shark Bay, however, suggest that consumption of gelatinous macroplankton is widespread and occurs in turtles not fitted with AVED. Indeed, mixing models suggest that although turtles between 40 and $60 \mathrm{~cm}$ likely consume relatively little gelatinous macroplankton, at least some individual turtles $\geq 60 \mathrm{~cm}$ CCL may get substantial energy from these invertebrates. New video data collected during this study suggest even higher foraging rates on gelatinous macroplankton than reported previously by Heithaus et al. (2002a).

Macroalgae also appear to be very important in the diets of green turtles in Shark Bay, even though their abundance is quite low relative to seagrasses in Shark Bay. Turtles $<60 \mathrm{~cm}$ likely derive almost all of their energy from macroalgae, and for larger turtles, macroalgae may make up half or more of their assimilated energy. While video data suggest that far more gelatinous macroplankton are consumed than macroalgae, it is possible that the nutritional content assimilated from these animals is lower than that obtained from seagrass or macroalgae. Regardless of the relative importance of macroalgae and gelatinous macroplankton for green turtles, seagrass and even seagrass epiphytes together, appear to represent $<5-20 \%$ of their assimilated energy. Video data seem to support the surprisingly low use of this abundant resource. Stable isotopic data do need to be interpreted with some caution, however. Hind-gut fermenters, like green turtles, may selectively route isotopes from different food sources to different purposes (Gannes et al. 1997, Martinez del Rio et al. 2009). Indeed, it appears that for some species, isotopes from high-protein food sources are more likely to be incorporated into tissues (Houpt \& Houpt 1968). If this is the case for green turtles, then seagrasses may be more important to their energy budgets than suggested by any of the mixing models we ran. If 
green turtles were exclusively, or even primarily, seagrass herbivores in Shark Bay, then variation in isotopic routing would be unlikely to produce such a diversity of isotopic values. The combination of isotopic, video, and lavage data strongly argues that non-epiphytic macroalgae and gelatinous macroplankton are important food sources for green turtles in Shark Bay.

The relatively high degree of omnivory in green turtles in Shark Bay is similar to findings from other areas of the world outside of the Caribbean. Upon recruitment to neritic habitats in Mauritania, green turtles do not make a rapid shift to an herbivorous diet as predicted (Cardona et al. 2009). Instead, many turtles continued to consume a largely animal-based diet. Isotopic mixing models suggest that animal prey, largely discards from local fisheries, accounted for $76-99 \%$ of the assimilated nutrients for animals between 29 and $59 \mathrm{~cm} \mathrm{CCL}$ and for $53-76 \%$ of the assimilated nutrients for animals with CCL $>59 \mathrm{~cm}$. Likewise, Cardona et al. (2010) found that green turtles in the Mediterranean did not make a rapid shift to an herbivorous diet upon recruitment to neritic habitats, but instead made a slow conversion to a primarily seagrass-based diet. Green turtles in the central Gulf of California fed on a diverse assemblage of marine algae, which was supplemented by a suite of animal matter with 25 non-algal food species being identified from esophageal lavage, fecal samples, and stomach contents (Seminoff et al. 2002). The relatively high degree of omnivory outside of the Caribbean, however, is not universal. Indeed, stomach lavage and limited stable isotopic data from Shoalwater Bay in northeastern Australia suggest diets largely supported by seagrass but also consisting of a relatively large amount of red algae (Arthur et al. 2009).

Green turtles have the ability to modify seagrass distributions in some locations with intense grazing (see Thayer et al. 1984 for a review). Excluding green turtles from Thalassia testudinum beds in Bermuda for $1 \mathrm{yr}$ resulted in a seagrass biomass increase, an increase in the structural complexity of the seagrass canopy, and an increase in the length and width of seagrass blades compared to seagrass in grazed plots (Fourqurean et al. 2010). Murdoch et al. (2007) documented large-scale seagrass declines in Bermuda where about half of the offshore and lagoonal seagrass beds, which are far-removed from anthropogenic impacts, were gone or in obvious decline during the period between 1997 and 2004. The authors suggest that herbivory by green turtles and other herbivores might be a leading factor in this decline. Our current study suggests that green turtles might be able to deal with a loss of seagrass by switching their diets to algae or gelatinous macroplankton, which might expand the impact that green turtles have on their environment by maintaining high population densities in the face of declining seagrass resources.

With more than $4000 \mathrm{~km}^{2}$ of seagrass in Shark Bay, it is quite surprising that turtle diets were not more similar to those in the Caribbean or Shoalwater Bay, where turtles rely heavily on seagrasses. Perhaps the relatively low use of seagrasses in our study area results from interspecific differences in the palatability of available seagrasses. However, in Moreton Bay, a seagrass-dominated ecosystem in northeast Australia, turtles include high proportions of macroalgae in their diets (Brand et al. 1999, Brand-Gardner et al. 1999). The slow-growing and relatively herbivoryresistant Amphibolis antarctica makes up the vast majority of the seagrass in the study area (Wirsing et al. 2007). Therefore, turtles may selectively forage on the less abundant but more palatable macroalgae and gelatinous plankton, or turtles may assimilate relatively little carbon from seagrass that is consumed. In addition to the generally low quality of $A$. antarctica, the $A$. antarctica found along the edges of seagrass banks, where turtles are forced to forage for most of the year as a result of the high risk of tiger shark Galeocerdo cuvier predation in the middle of banks, are of lower quality than the A. antarctica found in the interior of seagrass banks (Heithaus et al. 2007). Interestingly, the manatee-based mixing model suggested slightly higher use of seagrasses during winter, when turtles could access higherquality seagrass in the middle of banks because of relaxed predation risk. This is consistent with the observations that predation risk keeps turtles that are in good condition out of seagrass beds with highquality seagrass forage during summer months (Heithaus et al. 2007).

Although average diets of turtles in Shark Bay suggest relatively low rates of seagrass herbivory, it would be a mistake to assume that this translates to green turtles having little or no impact on the Shark Bay seagrass ecosystem. Indeed, ongoing exclosure experiments suggest a large impact of megagrazers (green turtles and dugongs) on the more palatable, but much less abundant, tropical seagrass species found in the study area (D. A. Burkholder unpubl. data). Furthermore, analysis of individual isotope values shows that some turtles had been feeding heavily on seagrasses, and it may take relatively few individual turtles to impact the dynamics of seagrass 
beds in Shark Bay, especially the growth and establishment of tropical species. Nonetheless, our results raise important questions about the dynamics of pristine seagrass communities. Green turtles are generally thought of as critical large herbivores that directly assimilate large amounts of seagrass-derived carbon into the food web (Bjorndal 1997, Jackson 1997, Valentine \& Duffy 2005, Heck \& Valentine 2007). However, in Shark Bay, green turtles appear to assimilate little seagrass-derived carbon, even when major portions of the Shark Bay food web are supported by seagrass-derived carbon. For example, the diverse ray and shark fauna are primarily feeding in seagrass-derived food webs and have $\delta^{13} \mathrm{C}$ values suggesting that these predators have a higher reliance on seagrass-derived carbon that is passed up the food chain than do green turtles in the same ecosystem (Vaudo \& Heithaus 2011).

\section{Individual specialization in turtle foraging?}

One of the most interesting aspects of green turtle foraging in Shark Bay was the extreme variation in isotopic values among individuals in the population. Variation among individual isotopic values can be driven by a number of factors, including short-term differences in diets (for tissues with rapid turnover), long-term specialization on a subset of a population's resources that vary in isotopic composition ('individual specialization'), or individual differences in physiology (Hobson \& Clark 1992, Bearhop et al. 2004, Barnes et al. 2008). We consider the latter explanation unlikely for green turtles in our study due to the extreme spread in isotopic values. Laboratory studies suggest that individual variation in isotopic composition in laboratory raised wild bass showed coefficients of variation $(\mathrm{CV})$ of $2.6 \%$ for $\delta^{15} \mathrm{~N}$, and $1.2 \%$ for $\delta^{13} \mathrm{C}$ (Barnes et al. 2008), while green turtle $\delta^{13} \mathrm{C}$ values in the present study spanned more than $10 \%$. Although differential isotopic routing of high-protein vs. low-protein food sources may somewhat amplify differences among individuals with different diets (e.g. Gannes et al. 1997), the extreme spread of isotopic values observed in green turtles suggests that other behavioral variation among individuals is important. Indeed, the total isotopic niche space (sensu Layman et al. 2007) of green turtles is the highest measured to date of the 11 species studied in Shark Bay. In fact, the isotopic niche space of green turtles is greater than the combined area of 213 individuals from 13 species of rays and small sharks (36.1; Vaudo \& Heithaus 2011) and the generalist tiger shark (13.9, n=93; M. R. Heithaus unpubl. data). Green turtles also covered a wider isotopic area than loggerhead turtles (J. A. Thomson unpubl. data), which are considered generalist foragers at a population level but may exhibit individual specialization in other parts of their range (Vander Zanden et al. 2010).

That green turtle isotopic values covered such a large area of isotopic niche space is surprising considering the relatively slow turnover rate of the turtle tissues sampled, and suggests that differences among individuals are the result of specialization over time frames of at least many months. Although not studied in green turtles, muscle tissue of pond slider turtles Trachemys scripta took hundreds of days to turnover (Seminoff et al. 2007). Larger body sizes and slow-growing tissues are generally associated with longer tissue turnover times (Martinez del Rio et al. 2009); therefore, it is likely that the slowly growing subadult and adult green turtle tissues collected during the present study represent diets over even longer time periods. Indeed, turnover times of skin tissue sampled from another large reptile (juvenile American alligators) were over 1 yr (A. Rosenblatt unpubl. data). Therefore, the extreme spread in individual green turtle tissues suggests specialization on particular suites of resources over periods of at least months (e.g. Bolnick et al. 2003). Such specialization has been hinted at for subadult green turtles off the coast of Africa that also displayed substantial variance in isotopic signatures (Cardona et al. 2009). Further studies are needed to further elucidate the degree to which green turtles specialize in their foraging and the duration of this potential specialization. Indeed, isotopic studies that allow greater resolution of patterns of specialization, i.e. using multiple tissue types with different turnover rates are required, such as muscle, whole blood, and blood plasma (Matich et al. 2011), or time series from inert tissues, such as scutes (Cardona et al. 2009, Vander Zanden et al. 2010). Incorporating other techniques for assessing trophic interactions (e.g. fatty acids, compound-specific stable isotopes, stomach contents analysis) would help to further resolve green turtle diet composition and patterns of specialization.

There are several possible drivers of specialization in Shark Bay green turtles. First, individual specialization is expected when resources are scarce and individuals can forage more efficiently by foraging on a narrow set of resources (Bolnick et al. 2003, Svanback \& Bolnick 2005, 2007, Tinker et al. 2008). The green turtle population in Shark Bay exhibits characteristics of one near carrying capacity (Heithaus et al. 2005), 
which may partially be driven by the presence of tiger sharks in more resource-rich microhabitats that force most turtles to forage in more concentrated areas on poorer food sources (Heithaus et al. 2007). Therefore, although Shark Bay appears to be resource-rich, intraspecific competition may drive specialization by green turtles in Shark Bay. Alternatively, herbivore diet specialization may result from the gut microfloral assemblage of each individual. Seagrasses and algae differ in their structural carbohydrates, and the gut microflora necessary to aid in digestion of seagrasses is different than that necessary for digestion of algae (Bjorndal et al. 1991), and therefore turtles with different microflora may consistently select different foods. Stomach content analysis of 26 green turtles on the Orman Reefs, Torres Strait, Australia, suggested some degree of specialization where 14 of the 26 turtles had stomach contents dominated by seagrasses, 11 were dominated by macroalgae, and while mixed diets were not uncommon, only one individual had approx. equal proportions of seagrass and macroalgae in its stomach at the time of analysis. In Shark Bay, it appears that individual specialization involves not only specialization on specific single resources but also on mixes of macroalgae, seagrasses, and pelagic gelatinous animals. Therefore, it is likely that additional factors other than variation in intestinal microflora drive specialization patterns. Finally, differences in trophic interactions could result from individual turtles inhabiting home ranges with different resource suites. For example, if individual home ranges encompass offshore (oceanic) habitats, which tend to be more carbon-deplete or other foraging grounds, then this may be able to account for some degree of variation in isotopic values (Reich et al. 2010, Vander Zanden et al. 2010). This explanation, however, seems unlikely in Shark Bay due to the large distances to oceanic habitats, the low displacement of turtles tagged with AVED or time-depth recorders (TDR) for periods of several days (J. A. Thomson unpubl. data), the similarity in benthic cover among banks where turtles were captured, and the lack of an effect of capture location on isotopic values. Detailed studies of turtle home ranges and movements are needed to adequately address this hypothesis.

\section{CONCLUSION}

Our study suggests that in relatively pristine ecosystems, like Shark Bay, green turtle foraging may be more complex than is generally appreciated and can be characterized by a relatively high degree of omnivory as well as individual specialization in foraging. Contrary to expectations, seagrass in this system is relatively unimportant to the assimilated carbon for green turtles, whereas macroalgae and animal tissue seem to be much more important and make up a much larger proportion of their diet. The relatively low food quality of seagrass within Shark Bay as well as foraging constraints imposed by the presence of tiger sharks (e.g. Heithaus et al. 2007, 2008) may partially drive the apparently low importance of seagrass to the turtle population as a whole. However, individual diet specialization in green turtles leads to some individuals foraging heavily on seagrass and highlights the importance of incorporating individual-level data on foraging and behavior into considerations of the ecological role of green turtles and management strategies for their protection.

Acknowledgements: We thank the Monkey Mia Dolphin Resort for providing lodging and logistical support. Special thanks to the numerous field assistants. J. Vaudo provided statistical advise. Thanks are also due to M. Donnelly and C. Layman for helpful comments on previous drafts of this manuscript. Funding for this project was provided by National Science Foundation grants OCE0526065 and OCE0745606 to M.R.H., Florida International University, and PADI Aware Grant \#253 to D.A.B. Research was conducted under DEC permits SF002752, NE002120, SF005394, CE001338, SF006804, CE002357 and subsequent annual renewals. Research was conducted with authorization from FIU's IACUC and with SFU UACC certification. This is contribution \#52 of the Shark Bay Ecosystem Research Project.

\section{LITERATURE CITED}

Alves-Stanley CD, Worthy GAJ (2009) Carbon and nitrogen stable isotope turnover rates and diet-tissue discrimination in Florida manatees (Trichechus manatus latirostris). J Exp Biol 212:2349-2355

Aragones LV, Marsh H (2000) Impact of dugong grazing and turtle cropping on tropical seagrass communities. Pac Conserv Biol 5:277-288

Aragones LV, Lawler IR, Foley WJ, Marsh H (2006) Dugong grazing and turtle cropping: Grazing optimization in tropical seagrass systems? Oecologia 149:635-647

Araújo MS, Gonzaga MO (2007) Individual specialization in the hunting wasp Trypoxylon (Trypargilum) albonigrum (Hymenoptera, Crabronidae). Behav Ecol Sociobiol 61: 1855-1863

Araújo MS, Bolnick DI, Martinelli LA, Giaretta AA, dos Reis SF (2009) Individual-level diet variation in four species of Brazilian frogs. J Anim Ecol 78:848-856

> Arthur KE, O'Neil JM, Limpus CJ, Abernathy K, Marshall G (2007) Using animal-borne imaging to assess green turtle (Chelonia mydas) foraging ecology in Moreton Bay, Australia. Mar Technol Soc J 41:9-13

Arthur KE, Boyle MC, Limpus CJ (2008) Ontogenetic changes in diet and habitat use in green sea turtle (Che- 
lonia mydas) life history. Mar Ecol Prog Ser 362:303-311 Arthur KE, McMahon KM, Limpus CJ, Dennison WC (2009) Feeding ecology of green turtles (Chelonia mydas) from Shoalwater Bay, Australia. Mar Turtle Newsl 123:6-12

Baird RW, Abrams PA, Dill LM (1992) Possible indirect interactions between transient and resident killer whales: implications for the evolution of foraging specializations in the genus Orcinus. Oecologia 89:125-132

Barnes C, Jennings S, Polunin NVC, Lancaster JE (2008) The importance of quantifying inherent variability when interpreting stable isotope field data. Oecologia 155: 227-235

> Bearhop S, Adams CE, Waldron S, Fuller RA, Macleod H (2004) Determining trophic niche width: a novel approach using stable isotope analysis. J Anim Ecol 73: 1007-1012

Bizzarro JJ, Robinson HJ, Rinewalt CS, Ebert DA (2007) Comparative feeding ecology of four sympatric skate species off central California, USA. Environ Biol Fishes 80:197-220

Bjorndal KA (1980) Nutritional and grazing behavior of the green turtle Chelonia mydas. Mar Biol 56:147-154

Bjorndal KA (1997) Foraging ecology and nutrition of sea turtles. In: Lutz PL, Musick JA (eds) The biology of sea turtles. CRC Press, Boca Raton, FL, p 199-231

Bjorndal KA, Jackson JBC (1996) Roles of sea turtles in marine ecosystems: reconstructing the past. In Lutz PL, Musick JA, Wyneken J (eds) The biology of sea turtles, Vol 2. CRC Press, Boca Raton, FL, p 259-273

Bjorndal KA, Suganuma H, Bolten AB (1991) Digestive fermentation in green turtles, Chelonia mydas, feeding on algae. Bull Mar Sci 48:166-171

> Bolnick DI, Svanback R, Fordyce JA, Yang LH and others (2003) The ecology of individuals: incidence and implications of individual specialization. Am Nat 161:1-28

- Borowitzka MA, Lethbridge RC, Charlton L (1990) Species richness, spatial distribution and colonisation pattern of algal and invertebrate epiphytes on the seagrass Amphibolis griffithii. Mar Ecol Prog Ser 64:281-291

Brand SJ, Lanyon JM, Limpus CJ (1999) Digesta composition and retention times in wild immature green turtles, Chelonia mydas: a preliminary investigation. Mar Freshw Res 50:145-147

Brand-Gardner SJ, Lanyon JM, Limpus CJ (1999) Diet selection by immature green turtles, Chelonia mydas, in subtropical Moreton Bay, south-east Queensland. Aust J Zool 47:181-191

> Cardona L, Aguilar A, Pazos L (2009) Delayed ontogenetic dietary shift and high levels of omnivory in green turtles (Chelonia mydas) from the NW coast of Africa. Mar Biol 156:1487-1495

Cardona L, Campos P, Levy Y, Demetropoulos A, Margaritoulis D (2010) Asynchrony between dietary and nutritional shifts during the ontogeny of green turtles (Chelonia mydas) in the Mediterranean. J Exp Mar Biol Ecol 393:83-89

Carruthers TJB, Dennison WC, Longstaff BJ, Waycott M and others (2002) Seagrass habitats of Northeast Australia: models of key processes and controls. Bull Mar Sci 71: 1153-1169

> Caut S, Angulo E, Courchamp F (2009) Variation in discrimination factors $\left(\Delta^{15} \mathrm{~N}\right.$ and $\left.\Delta^{13} \mathrm{C}\right)$ : the effect of diet isotopic values and applications for diet reconstruction. J Appl Ecol 46:443-453

- Chaloupka M, Limpus CJ (2001) Trends in the abundance of sea turtles resident in southern Great Barrier Reef waters. Biol Conserv 102:235-249

> Darimont CT, Paquet PC, Reimchen TE (2009) Landscape heterogeneity and marine subsidy generate extensive intrapopulation niche diversity in a large terrestrial vertebrate. J Anim Ecol 78:126-133

> DeNiro MJ, Epstein S (1981) Influence of diet on the distribution of nitrogen isotopes in animals. Geochim Cosmochim Acta 45:341-351

Ehrhart LM, Ogren LH (1999) Studies in foraging habitats: capturing and handling turtles. In: Eckert KL, Bjorndal KA, Abreu-Grobois FA, Donnelly M (eds) Research and management techniques for the conservation of sea turtles. IUCN/SSC Marine Turtle Specialist Group Publication, Vol 4. Consolidated Graphic Communications, Blanchard, PA, p 61-65

Estes JA, Reidman ML, Staedler MM, Tinker MT, Lyon BE (2003) Individual variation in prey selection by sea otters: patterns, causes, and implications. J Anim Ecol 72: $144-155$

Felicetti LASC, Rye RO, Haroldson MA, Unther KA, Philips DL, Robbins CT (2003) Use of sulphur and nitrogen stable isotopes to determine the importance of whitebark pine nuts to Yellowstone grizzly bears. Can J Zool 81: $763-770$

Forbes GA (1994) The diet of the green turtle in an algalbased community - Heron Island, Australia. In: Schroeder BA, Witherington BE (eds) Proceedings of the Thirteenth Annual Symposium on Sea Turtle Biology and Conservation. NOAA Tech Memo NMFS-SEFSC-341. Department of Commerce, Washington, DC, p 57-59

> Forbes GA, Limpus C (1993) A non-lethal method for retrieving stomach contents from sea turtles. Wildl Res 20:339-343

Fourqurean JW, Manuel S, Coates KA, Kenworthy WJ, Smith SR (2010) Effects of excluding sea turtle herbivores from a seagrass bed: Overgrazing may have led to loss of seagrass meadows in Bermuda. Mar Ecol Prog Ser 419:223-232

Gannes LZ, O'Brien DM, Martinez del Rio C (1997) Stable isotopes in animal ecology: assumptions, caveats, and a call for more laboratory experiments. Ecology 78: 1271-1276

Hamann M, Godfrey MH, Seminoff JA, Arthur K and others (2010) Global research priorities for sea turtles: informing management and conservation in the 21st century. Endang Species Res 11:245-269

- Hammerschlag-Peyer CM, Layman CA (2010) Intrapopulation variation in habitat use by two abundant coastal fish species. Mar Ecol Prog Ser 415:211-220

> Harrison SM, Zazzo A, Baha B, Monahan FJ, Moloney AP, Scrimgeour CM, Schnidt O (2007) Using hooves for highresolution isotopic reconstruction of bovine dietary history. Rapid Commun Mass Spectrom 21:479-486

> Heck KL, Valentine JF (2007) The primacy of top-down effects in shallow benthic ecosystems. Estuaries Coasts 30:371-381

> Heithaus MR, McLash JJ, Frid A, Dill LM, Marshall GJ (2002a) Novel insights into green sea turtle behaviour using animal-borne video cameras. J Mar Biol Assoc UK 82:1049-1050

Heithaus MR, Frid A, Dill LM (2002b) Species and sex-class differences in shark inflicted injury frequencies, escape ability, and habitat use of green and loggerhead turtles. Mar Biol 40:229-236 
Heithaus MR, Frid A, Wirsing A, Bejder L, Dill LM (2005) Biology of sea turtles under risk from tiger sharks at a foraging ground. Mar Ecol Prog Ser 288:285-294

Heithaus MR, Wirsing AJ, Frid A, Dill LM (2007) Species interactions and marine conservation: lessons from an undisturbed ecosystem. Israel J Ecol Evol 53:355-370

Heithaus MR, Frid A, Wirsing AJ, Worm B (2008) Predicting ecological consequences of marine top predator declines. Trends Ecol Evol 23:202-210

> Hobson KA, Clark RG (1992) Assessing avian diets using stable isotopes I: turnover of ${ }^{13} \mathrm{C}$ in tissues. Condor 94 : 181-188

> Hooker SK, Iverson SJ, Ostrom P, Smith SC (2001) Diet of northern bottlenose whales inferred from fatty-acid and stable-isotope analyses of biopsy samples. Can J Zool 79: 1442-1454

> Houpt TR, Houpt KA (1968) Transfer of urea nitrogen across the rumen wall. Am J Physiol 214:1296-1303

Hyslop EJ (1980) Stomach content analysis - a review of methods and their application. J Fish Biol 17:411-429

> Jackson JBC (1997) Reefs since Columbus. Coral Reefs 16: S23-S32

> Jackson JBC, Kirby MX, Berger WH, Bjorndal KA and others (2001) Historical overfishing and the recent collapse of coastal ecosystems. Science 293:629-637

> Kuiper-Linley M, Johnson CR, Lanyon JM (2007) Effects of simulated green turtle regrazig on seagrass abundance, growth and nutritional status in Moreton Bay, south-east Queensland, Australia. Mar Freshw Res 58:492-503

> Lal A, Arthur R, Marbá N, Lill AWT, Alcoverro T (2010) Implications of conserving an ecosystem modifier: Increasing green turtle (Chelonia mydas) densities substantially alters seagrass meadows. Biol Conserv 143: 2730-2738

Layman CA, Arrington DA, Montana CG, Post DM (2007) Can stable isotope ratios provide for community-wide measures of trophic structure? Ecology 88:42-48

Martinez del Rio C, Wolf BO (2005) Mass balance models for animal isotope ecology. In: Starck MA, Wang T (eds) Physiological and ecological adaptations to feeding in vertebrates. Science Publishers, Enfield, NH, p 141-174

Martinez del Rio C, Wolf N, Carleton SA, Gannes LZ (2009) Isotopic ecology ten years after a call for more laboratory experiments. Biol Rev Camb Philos Soc 84:91-111

- Matich P, Heithaus MR, Layman CA (2011) Contrasting patterns of individual specialization and trophic coupling in two marine apex predators. J Anim Ecol 80:294-305

Minagawa M, Wada E (1984) Stepwise enrichment of ${ }^{15} \mathrm{~N}$ along food chains: further evidence and the relation between $15 \mathrm{~N}$ and animal age. Geochim Cosmochim Acta 48:1135-1140

> Moore JW, Semmens BX (2008) Incorporating uncertainty and prior information into stable isotope mixing models. Ecol Lett 11:470-480

> Moran KL, Bjorndal KA (2005) Simulated green turtle grazing affects structure and productivity of seagrass pastures. Mar Ecol Prog Ser 305:235-247

Mortimer JA (1981) The feeding ecology of the West Caribbean green turtle (Chelonia mydas) in Nicaragua. Biotropica 13:49-58

Murdoch TJT, Glasspool AF, Outerbridge M, Ward J and others (2007) Large-scale decline in offshore seagrass meadows in Bermuda. Mar Ecol Prog Ser 339:123-130

Newsome SD, Tinker MT, Monson DH, Oftedal OT and others (2009) Using stable isotopes to investigate individual diet specialization in California sea otters (Enhydra lutris nereis). Ecology 90:961-974

Peterson BJ, Fry B (1987) Stable isotopes in ecosystem studies. Annu Rev Ecol Syst 18:293-320

Post DM (2002) Using stable isotopes to estimate trophic position: models, methods, and assumptions. Ecology 83: 703-718

> Post DM, Layman CA, Arrington DA, Takimoto G, Montaña CG, Quattrochi J (2007) Getting to the fat of the matter: models, methods and assumptions for dealing with lipids in stable isotope analyses. Oecologia 152:179-189

Read MA, Limpus CJ (2002) The green turtle, Chelonia mydas, in Queensland: feeding ecology of immature turtles in Moreton Bay, Southeastern Queensland. Mem Queensl Mus 48:207-214

Reich KJ, Bjorndal KA, Bolten AB (2007) The 'lost years' of green turtles: using stable isotopes to study cryptic lifestages. Biol Lett 3:712-714

Reich KJ, Bjorndal KA, Martinez del Rio C (2008) Effects of growth and tissue type on the kinetics of ${ }^{13} \mathrm{C}$ and ${ }^{15} \mathrm{~N}$ incorporation in a rapidly growing ectotherm. Oecologia 15:651-663

Reich KJ, Bjorndal KA, Frick MG, Witherington BE, Johnson C, Bolten AB (2010) Polymodal foraging in adult female loggerheads (Caretta caretta). Mar Biol 157:113-121

> Rendell L, Whitehead H (2001) Culture in whales and dolphins. Behav Brain Sci 24:309-324

- Rosenblatt AE, Heithaus MR (2011) Does variation in movement tactics and trophic interactions among American alligators create habitat linkages? J Anim Ecol 80: 786-798

Seminoff JA, Resendiz A, Nichols WJ (2002) Diet of east Pacific green turtles (Chelonia mydas) in the Central Gulf of California, Mexico. J Herpetol 36:447-453

Seminoff JA, Jones TT, Marshall GJ (2006a) Underwater behavior of green turtles monitored with video-timedepth recorders: what's missing from dive profiles? Mar Ecol Prog Ser 322:269-280

Seminoff JA, Jones TT, Eguchi T, Jones DR, Dutton PH (2006b) Stable isotope discrimination $\left(\delta^{13} \mathrm{C}\right.$ and $\left.\delta^{15} \mathrm{~N}\right)$ between soft tissues of the green sea turtle Chelonia mydas and its diet. Mar Ecol Prog Ser 308:271-278

Seminoff JA, Bjorndal KA, Bolten AB (2007) Stable carbon and nitrogen isotope discrimination and turnover in pond sliders Trachemys scripta: insights for trophic study of freshwater turtles. Copeia 2007:534-542

Svanbäck R, Bolnick DI (2005) Intraspecific competition affects the strength of individual specialization: an optimal diet theory method. Evol Ecol Res 7:993-1012

Svanbäck R, Bolnick DI (2007) Intraspecific competition drives increased resource use diversity within a natural population. Proc Biol Sci 274:839-844

Svanbäck R, Persson L (2004) Individual diet specialization, niche width, and population dynamics: implications for trophic polymorphisms. J Anim Ecol 73:973-982

Thayer GW, Engel DW (1982) Evidence for short circuiting of the detritus cycle of seagrass beds by the green turtle Chelonia mydas. J Exp Mar Biol Ecol 62:173-183

Thayer GW, Bjorndal KA, Ogden JC, Williams SL, Zieman JC (1984) Role of larger herbivores in seagrass communities. Estuaries 7:351-376

Tinker MT, Bentall G, Estes JA (2008) Food limitation leads to behavioral diversification and dietary specialization in sea otters. Proc Natl Acad Sci USA 105:560-565 
Valentine JF, Duffy JE (2005) The central role of grazing in seagrass ecology. In: Larkum AWD, Orth RJ, Duarte CM (eds) Seagrasses: biology, ecology and conservation. Springer, Dordrecht, p 463-501

Vander Zanden HB, Bjorndal KA, Reich KJ, Bolten AB (2010) Individual specialists in a generalist population: results from a long-term stable isotope series. Biol Lett 6: 711-714

Vaudo J, Heithaus MR (2011) Dietary niche overlap in a nearshore elasmobranch mesopredator community. Mar Ecol Prog Ser 425:247-260

Wabnitz CCC, Balazs G, Beavers S, Bjorndal KA and others (2010) Ecosystem structure and processes at Kaloko Hanokohau, focusing on the role of herbivores, including

Editorial responsibility: Kenneth Heck Jr., Dauphin Island, Alabama, USA the green sea turtle Chelonia mydas, in reef resilience. Mar Ecol Prog Ser 420:27-44

> Walker DI, McComb AJ (1988) Seasonal variation in the growth, biomass, and nutrient status of Amphibolis antarctica (Labill. Sonder ex Aschers. and Posidonia australis Hook. f. in Shark Bay, Western Australia. Aquat Bot 31:259-275

- Walker DI, Kendrick GA, McComb AJ (1988) The distribution of seagrass species in Shark Bay, Western Australia, with notes on their ecology. Aquat Bot 30:305-317

Wirsing AJ, Heithaus MR, Dill LM (2007) Living on the edge: dugongs prefer to forage in microhabitats that allow escape from rather than avoidance of predators. Anim Behav 74:93-101

Submitted: December 6, 2010; Accepted: July 25, 2011

Proofs received from author(s): October 4, 2011 